\title{
MODELLING AND SIMULATION OF GASOLINE ENGINE AT DIFFERENT LOAD CONDITIONS USING OXYHYDROGEN BLEND
}

\author{
SHRIKANT BHARDWAJ ${ }^{1} \&$ ARVIND JAYANT ${ }^{2}$ \\ ${ }^{1}$ Mechanical Engineering Department, Sant Longowal Institute of Technology, Longowal, India \\ ${ }^{2}$ School of Engineering \&Technology, ASIAN Institute of Technology (AIT), Bangkok, Thailand
}

\begin{abstract}
The demand for fossil fuels is increasing regularly; therefore Researchers are facing the challenge of finding promising alternative fuels such as hydrogen, oxyhydrogen, alcohol, biodiesel fuels etc. Some of the adverse effects of the current fuel technology prevailing in internal combustion engines are poor air quality index, increased accumulation of greenhouse gases in the environment. The aim of present research was to generate the oxyhydrogen gas through the process of electrolysis and send the homogeneous mixture of gasoline and oxyhydrogen into the four cylinder four stroke spark ignition engine and then analyse emission and performance parameters. Oxyhydrogen gas was manipulated as a secondary fuel in spark ignited 1298 cc engine. Results obtained conclude that by using oxyhydrogen and gasoline mixture the r.p.m increased by $9 \%$, fuel consumption decreased by $10.80 \%$, brake power increased by $8.61 \%$, indicated power increased by $12.63 \%$ whereas indicated and brake specific fuel consumption decreased by $21.18 \%$ and $18.17 \%$ respectively, also the emission of hydrocarbon decreased by $8.25 \%$ and carbon monoxide decreased by $6.05 \%$. The drawback of this research setup was the increase in frictional losses due to high heat generation which accompany the reduction in mechanical efficiency by 4.31\%. Oxyhydrogen generator and supplying system can be made compatible to the engine without any major modification which approaches towards better results.

KEYWORDS: I.C Engine, Oxyhydrogen Gas, Emission, Performance Parameters, Efficiency, HHO \& Fuel
\end{abstract}

Received: Jun 06, 2020; Accepted: Jun 26, 2020; Published: Aug 28, 2020; Paper Id.: IJMPERDJUN2020937

\section{NOMENCLATURE}

$\begin{array}{clrl}\text { I.C } & \text { Internal Combustion } & \text { S.I } & \text { Spark Ignition } \\ \text { HHO } & \text { Oxyhydrogen/Brown Gas } & \text { C.I } & \text { Compression Ignition } \\ \mathrm{H}_{2} & \text { Hydrogen } & \text { B.G } & \text { Brown Gas } \\ \mathrm{NO}_{x} & \text { Nitrogen Oxides } & \text { sfc } & \text { Specific fuel consumption } \\ \text { L.P.M } & \text { Liters per Minute } & \text { bsfc } & \text { Brake Specific fuel consumption } \\ \mathrm{CO}_{2} & \text { Carbon dioxide } & \text { isfc } & \text { Indicated Specific fuel consumption } \\ \mathrm{HC} & \text { Hydrocarbon } & \text { I.P } & \text { Indicated Power } \\ \mathrm{PM} & \text { Particulate Matter } & \text { B.P } & \text { Brake Power } \\ \mathrm{CA} & \text { Crank Angle } & \text { B.T.E } & \text { Brake Thermal Efficiency } \\ \text { EGT } & \text { Exhaust Gas Temperature } & \text { SOFC } & \text { Solid Oxide Fuel Cells } \\ \text { WCO } & \text { Waste Cooking Oil } & \text { RCCI } & \text { Reactivity Controlled Compression Ignition } \\ \text { THC } & \text { Total Hydro Carbon } & \lambda & \text { Coefficient of Excess Air Ratio }\end{array}$




\section{INTRODUCTION}

The expeditious degradation of our surroundings and unprediciatiability regarding future energy reservoirs are result of our present behaviour relied on peculiaramenity and maneuverability. Several researches in the past were carried out for enhancement of both S.I and C.I engines. Hydrogen is the lightest element in the periodic table and has an atomic mass of 1.008 a.m.u. Oxyhydrogen gas is a blend of one atom of oxygen and two atoms of hydrogen gas, in a monoatomic state bearing the 1:2 atomic ratio. Hydrogen has very high flammability limits of 0.04-0.75 by volume in air compared to diesel of $0.007-0.05$ by volume and for petrol it is 0.014 to 0.076 . The high diffusibility of hydrogen makes it easier to mix the fuel and air along with it, so that a uniform mixture can be sent to the combustion chamber. Electrolysis cell is used to provide oxyhydrogen to the engine and helped to investigate the overall emission and performance state of spark ignition engine.

Khatri et al. investigated the use of hydrogen gas with dissimilar blending compositions between biogas and diesel in dual fuel mode single cylinder stationary C.I engine. Three varieties of duel fuels were prepared using the hydrogen, biogas and diesel as the core composition elements. The fuels compositions were as follows:biogas- diesel, hydrogen-biogasdiesel, biogas- diesel, hydrogen- diesel. The experimental investigation was carriedon the compatibility and superiority of these fuels, from the experiment it was calculated that the hydrogen-biogas-diesel was the optimum among the three types and it provided better results in emission and performance of the C.I engine. For hydrogen-biogas-diesel fuel the most suitable injection timing was obtained on $21^{\circ} \mathrm{CA}^{1}$. Sharma et al. performed an experimental work of using $\mathrm{HHO}$ at different flow rates of $0,0.25,0.5,0.75 \mathrm{lpm}$ with dual fuel mode C.I engine. A deep interpretation was carried out on the exergy, emission and energy analysis of HHO fueled in C.I engine at constant load conditions. It was concluded that an increase of $6.5 \%$ in BTE, $6.29 \%$ in heat transfer losses, $8.55 \%$ in exhaust gas losses and nearly 35\% increase in NOx emission was acquired at $0.75 \mathrm{lpm}$ of oxyhydrogen gasat $80 \%$ load conditions ${ }^{2}$.Deheri et al. carried out a very vital review on the emission, performance, peak temperature and pressure inside the dual fuel C.I engine. In this review work a detailed analysis was performed on the future use of alternative fuels in C.I engine and its optimization in energy terms and conditions. Depreciation was observed in BTE and EGT in the range of 2 to $22 \%$ with an increase of nearly $36 \%$ in bsfc. The enhancement in $\mathrm{HC}$ and $\mathrm{CO}$ content was observed in emission when biogas was used in comparison with diesel only ${ }^{3}$.Salek et al. investigated effect of different parameters both internal and external like shape of the electrodes, distance between the electrodes, magnetic effect on electrodes and use of ultrasonic pulses over the bubbles formation rate and HHO gas production rate by the electrolysis cell. It was concluded that the flat shaped plates with $2 \mathrm{~mm}$ gap have the maximum HHO generation rate with minimum energy intensity ${ }^{4}$ Xu et al. developed a hybrid model of SOFCs using the MPS and DNN amalgamation. It was concluded that a very good online prediction model with an error of less than $1 \%$ developed with the decrease in gas temperature at cathode due to increase in flow rate of gas at anode end ${ }^{5}$.Mourad et al. carried out an analysis on the use of blending mixture of ethanol/butanol with gasoline in S.I engine at different levels of mixing percentages varied from $0 \%$ to $20 \%$. The result declared that the combination of EB15 was the best blending mixture overall. The reduction in HC,CO was attained with $11 \%$ decrease in power output ${ }^{6}$. Abe et al. investigated the different methods presently available which can be employed for the storage of hydrogen and from where latter the hydrogen can be utilised as per the requirement. Out of various hydrogen storing techniques the metal hydrides was found to be the best one but with certain limitations which form the future scope of the present solid state storage techniques ${ }^{7}$. Neshat et al. studied the impact of addition of water to the combustion, performance and emission parameters on C.I engine. It concluded that addition of water decreases the temperature of combustion chamber but increases the quantity of soot in exhaust emission. A slight enhancement in engine efficiency was obtained for very small quantity of water addition ${ }^{8}$. Senthil et al. observed consequences of using ethanol and 
WCO as low reactivity and high reactivity fuelin single cylinder C.I engine under RCCI mode. In this mode the BTE increased by $33.5 \%$ as compared to $29.6 \%$ of WCO. The reduction in NO, HC and CO were obtained ${ }^{9}$.Choodum et al. produced the $\mathrm{HHO}$ gas through electrolysis and after generating $\mathrm{HHO}$ at different conditions like plate gap, working temperature, electrolyte concentration optimized the $\mathrm{HHO}$ generation rate. The optimized condition for HHO generation rate was $90^{\circ} \mathrm{C}$ working temperature, Cell gap of $7 \mathrm{~mm}$ and $1.50 \%$ of electrolyte solution ${ }^{10}$. Karagöz et al. interpreted performance parameters and emission for four stroke one cylinder S.I engine also used the theoretical model of AVL. In this a comparison was made between pure gasoline and pure hydrogen when used as fuel. It was concluded that the CO, THC were almost vanished with enhancement in brake thermal efficiency for pure hydrogen as fuel but the NOx formation emerged as a problem on use of pure hydrogen which was latter resolved using a very lean mixture of hydrogen with air excess coefficients $(\lambda=2)^{11}$.Koten. $\mathrm{H}$ investigated the hydrogen effect on a water cooled four stroke engine C.I engine. Inclusion of hydrogen reduced emission problem and also supports the complete combustion of diesel fuel. Different ratio of hydrogen addition was done at different load conditions but it was concluded that $0.80 \mathrm{lpm}$ generates the optimized results ${ }^{12}$.Ammar A. AlRousan had done the work on decrease of consumption of fuel by HHO gas. HHO and Gasoline are the inputs. Here in this testing, a fuel cell was attached to give HHO gas to intake manifold in order to reduced fuel consumption, pollution and exhaust temperature. The results showed that ideal amount of HHO gas when generated from the electrolyzer required nearly 20 times of area when compared with that of surface area of piston ${ }^{13}$. Hajlari et al.worked on biodiesel production from castor oil and its effect on performance of diesel engine in the journal of Renewable Energy. Castor oil was used as biodiesel. Four loads $(25,50,75 \& 100 \%)$ and two speeds (1500 \& 2000rpm) were tested on OM-314 direct injection engine ${ }^{14}$. Sakthivel et al. predicted the C.I engine combustion parameters, performance, and emission using biodiesel obtained from fish oil by applying fuzzy-GA. The inputs were blend of fish oil and diesel. Fuzz logic and Genetic algorithm have been used to make best blend of fish oil and diesel and predicted the performance \& emission characteristics. The results concluded decrease in brake thermal efficiency by $1.8 \%$ to $12.9 \%, \mathrm{HC}$ by $1.2 \%, \mathrm{CO}_{2}$ increased by $1.2 \%, \mathrm{NOx}$ decreased by $2.3 \% 15$. Kumar et al. investigated injection techniques of ethanol and water conduction in engine. The engine used was dual fuel engine. Brake thermal efficiency increased from $25.2 \%$ to $28.5 \%$ with $\mathrm{H}_{2}$ and $30 \%$ with ethanol ${ }^{16}$. Birtas et al. worked on likelihood to enhanced use of laser ignition in a petrol engine operation. Laser ignition system was used to improve engine power and reduce combustion duration. The results showed that in stoichiometric mixture no improvement was observed whereas in lean mixture, it improved power by $27 \%$. Laser ignition system can be used in petrol engine ${ }^{17}$. Nabi et al. developed one dimensional thermodynamics model for testing the engine parameters and carried out combustion analysis. GT-suit stimulation software was used for analysis. Decane and dodecane showed higher BTE and lower BSFC, soot emission was less as resultant ${ }^{18}$. Chizoo et al. worked on modelling of engine. The inputs were bio-diesel \& diesel. Multiinput, output, ANN and Nerder Meed's were used to study engine performance, combustion and emission. Fuel consumption and emission was reduced with enhancement in thermal efficiency ${ }^{19}$.Onawumi et al. applied the surface methodology technique to study S.Iengine parameters. Response surface methodology has been utilized here to determine the S.I engine performance. Loading condition, engine speed and time affect the emission ${ }^{20}$. Osama et al. worked on the effect of water injection technique in hydrogen-diesel dual fuel engine. Water injection technique was used and also GT software was used to analyse the combustion performance. The results showed that cylinder temperature, engine brake power, BSFC, NOx increases, BTE decreased ${ }^{21}$. Sheykhi et al. investigated the performance of an integrated power and heat system with internal and external combustion engines. The purpose was to investigate performance of I.C and Stirling engine. The results concluded that power efficiency, thermal efficiency and energy saving increases ${ }^{22}$. Güven et al. concentrated on optimization 
of waste heat recovery from engine of a heavy duty truck using Stirling engine. Waste heat recovery system was used to reduce fuel consumption and clean engine. I.C engine power enhanced by $1.3 \%$ and fuel consumption reduced by $1 \%{ }^{23}$. Nour et al. worked on higher alcohol and diesel blends in single cylinder diesel engines with necessary sensors. BSFC and BTE increased while alcohol and ignition delay also increased with higher alcohol ${ }^{24}$. Hassantabar et al. investigated the effect of altitude and engine speed TBI system of an air-powered two-stroke engine. Throttle body injection system and lotus engine stimulation were used to check the execution of fuel injection in TBE.It was concluded that enhancement in speed increased the power and with height the air-pressure in throttle body decreased ${ }^{25}$.Qian et al. worked on dual fuel S.I engine to study the effect of spark and injection timing of ethanol in engine cylinder. The results concluded that rapid combustion duration increased, NOx, $\mathrm{HC}$ decreased $^{26}$.

The research covered all possible future enhancements for the engine and to develop its emission and performance parameters. The investigation concentrates on blending of different compositions of fuels together in order to attain a new fuel with combination of the blending fuel characteristics. It also concentrates on the green engine technology using fuel cell concept for future use, different fuel filtration and blending processes and also work on the new concept of decreasing the engine cylinder linear wear ${ }^{13}$.

\subsection{Objective}

This purpose of this work was to study the compatibility of generating the oxyhydrogen gas from the water through electrolysis on stipulation at the point of operation, to enhance decrement of emission and consumption of fuel in S.I engine. The objective of this worklookout was to envelop two petitions:

- On-board generation of hydrogen rich gas at the time of demand.

- Enhancement of the engine efficiency, fuel consumption reduction and decrement in exhaust emissions of gasoline engine.

\subsection{Oxyhydrogen Thrift}

In the present time, there is need to emphasize the usage and development in technology regarding the use of hydrogen. Hydrogen economy refers to the emphasis laid on the sustainable growth of technologies which promote the use of hydrogen. Hydrogen as a fuel possesses large number of benefits along with the fact that it is one of the most abundant materials on the earth. Another advantage is that water can be easily dissociated into oxygen and hydrogen by passing a direct current across it. The oxyhydrogen gas successfully carried out the combustion in the engine with a very lean charge. It also nullify the possibility of NOx formation when the value of $\lambda=0.9$ which is also considered to be the optimum for the hydrogen fuel combination. When the value of $\lambda$ higher than 1.4 a very lean mixture carries out the combustion and under this condition the final combustion temperature achieved also decreases. It can also be used as a fuel in the aerospace industry because it makes very high quality of fuel ${ }^{27}$.

\subsection{Chemical Reactions Involved}

At Cathode Terminal: $2 \mathrm{H}_{2} \mathrm{O}(l)+2 \mathrm{e}^{-} \rightarrow \mathrm{H}_{2}(g)+2 \mathrm{OH}(a q)$

At Anode Terminal: $4 \mathrm{OH} \rightarrow \mathrm{O}_{2}(g)+2 \mathrm{H}_{2} \mathrm{O}(l)+4$ e-

Overall Reaction: $2 \mathrm{H}_{2} \mathrm{O}(l) \rightarrow 2 \mathrm{H}_{2}(g)+\mathrm{O}_{2}(g)$ 


\section{EXPERIMENTAL SET-UP}

Electrolysis of water is a phenomenon of mortify a solution by advances direct electric current through it. The temperature within a range of 100 degree Celsius is considered to be the excellence working condition, in this the $\mathrm{ETN}=\Delta H^{\circ} / 2 \mathrm{~F} \approx 1.48$ $\mathrm{V}$ which is moderately contingent upon the pressure. Threshold condition for the electrolysis to begin when a cell voltage $U$ $>$ Eo. The energy is absorbed by the electrolysis process from its surroundings when $\mathrm{U}<\mathrm{E} T N$. The segregation of water molecules into its prime constituent takes place at constant temperature for the thermoneutral cell voltage. The electrolytic cell becomes exothermic when the applied voltage is higher than the thermoneutral voltage and the energy is liberated in the surrounding, this exothermic reaction raises the temperature of the cell and provide a very vital constraint to the use of electrolysis cell phenomena for the use of generation of oxyhydrogen cell ${ }^{28}$.

Studies are being conducted to design a set up for on board hydrogen generation. One method for doing it can be regeneration of hydrogen from vehicle's fuel supply or generating hydrogen from electrolysis of water.

Oxyhydrogen gas is produced from the electrolysis of water, when a direct current is applied across its terminals. The composition of oxyhydrogen gas is quite different from that of water composition, as in water hydrogen is in diatomic form but here in oxyhydrogen gas it remained in monoatomic form. Bonding of HHO is also quite different from that of water; structure formula of $\mathrm{HHO}((\mathrm{H} \times \mathrm{H})-\mathrm{O})$ includes the magnecular $(\mathrm{X})$ bond instead of linear $(-)$ traditional bond of water $(\mathrm{H}-\mathrm{O}-\mathrm{H})$.

Conversation of traditional $\mathrm{H}-\mathrm{O}-\mathrm{H}$ to latest $(\mathrm{H} \times \mathrm{H})-\mathrm{O}$ family was anticipated by the transformation of electric dispersion of solution of water generated by the electrolytic cell. The direct upgradation of water into the oxyhydrogen gas is explained by the new configuration bonding of $\mathrm{HHO}$. The $(\mathrm{H} \times \mathrm{H})-\mathrm{O}$ is forecasted to be the unstable gas as here $\mathrm{H}-\mathrm{O}-\mathrm{H}$ is liquid and $\mathrm{HHO}$ is in gaseous state from the beginning of its formation and this conversation of state takes place without any evaporation and is considered to be the exceptional conduct of oxyhydrogen $\operatorname{gas}^{29}$.

Pure water + Potassium hydroxide + Direct Current $=$ Oxyhydrogen Gas

This gas is then transferred into combustion chamber where it burns along with fuel and air.

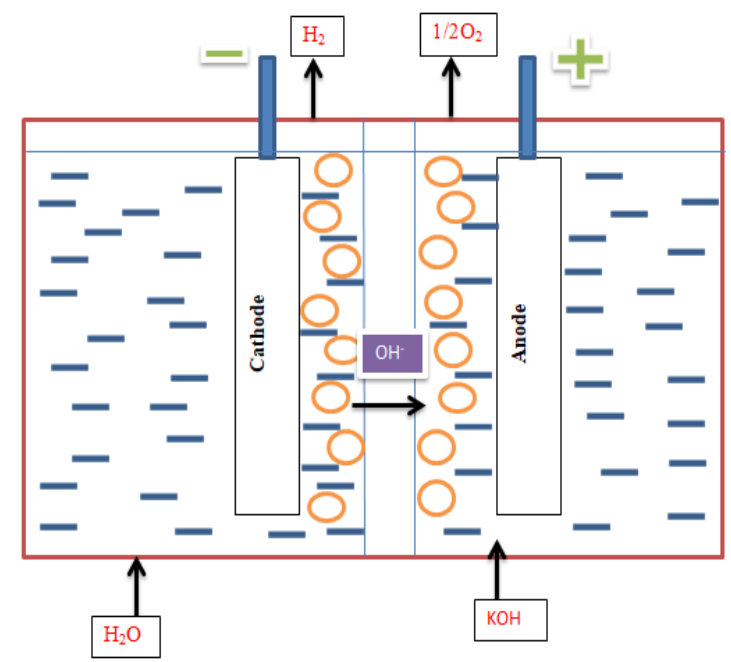

Figure: 1: Electrolytic Cell Diagram. 


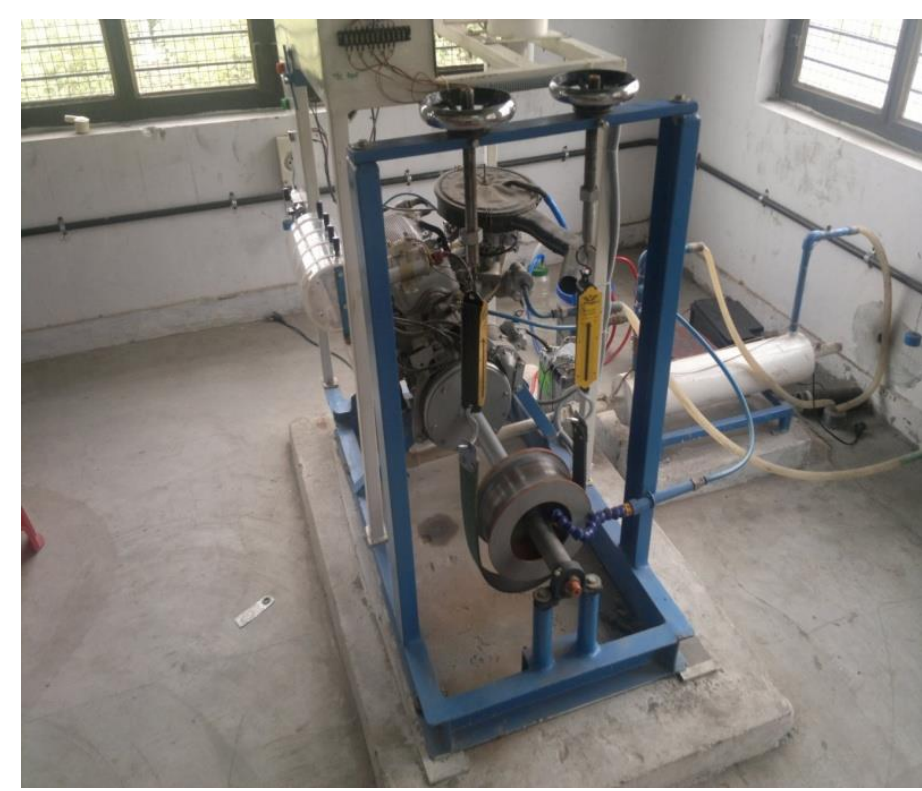

Figure 2: Experimental Setup.

\subsection{Generator Power Input}

It is worth noting that hydrogen gas has no colour, smell or taste. It is also a non-corrosive gas and is not toxic to humans. To generate the oxyhydrogen gas utilizing the method of electrolysis accurate mixture of distilled water solution with potassium hydroxide or sodium hydroxide is very significant. The amount of the power incumbent in order to carry out the process of oxyhydrogen gas generation through electrolysis calculated using the formula:

$$
\begin{aligned}
\text { Power required } & =\text { Voltage } \times \text { Current } \\
P & =V \times I
\end{aligned}
$$

\subsection{Electrode Arrangement}

The electrodes were placed in a very conventional mannerandstainless steel $304 \mathrm{~L}$ had been used for the making of cell. At the cathode end of the cell hydrogen gas is generated and at the anode end of the pure oxygen gas is generated. The Stainless steel $304 \mathrm{~L}$ is selected for the plates of the cell because it is very good corrosion resistant and also easily available.

\subsection{Hydrogen Bubbler}

Oxyhydrogen and hydrogen are very flammable gases, they both can create havoc if uncontrolled combustion takes place or some leakage problem arises. In order to provide the safety we used a safety device called hydrogen bubbler. This is avery important device and controlled the back flame condition during the injection of oxyhydrogen gas into the engine for combustion.

\subsection{Working of Engine with Hydrogen}

The hydrogen is generated at the cathode end of the generator and this hydrogen is fed to the engine through the inlet manifold passing through the carburettor. Avoid is created by themanoeuvre of piston from TDC to BDC The combustion takes place in the oxyhydrogen and fuel blend and there-after the low ignition temperature of hydrogen makes it easier to burn the complete fuel in one cycle. 
HHO itself contains $33.3 \%$ of oxygen by volume and $66.7 \%$ of hydrogen. The detonation of homogeneous blends of oxyhydrogen and gasoline is 3 times quick that of petrol detonation inside the combustion chamber of the engine. Hydrogen gas is fourteen cadences lighter than air rising at $20 \mathrm{~m} / \mathrm{s}$. Therefore a good hike in the mileage of spark ignition engine was obtained. The hydrogen gas have very good combustion rate in comparison to that of gasoline alone.

\section{ENGINE SPECIFICATION}

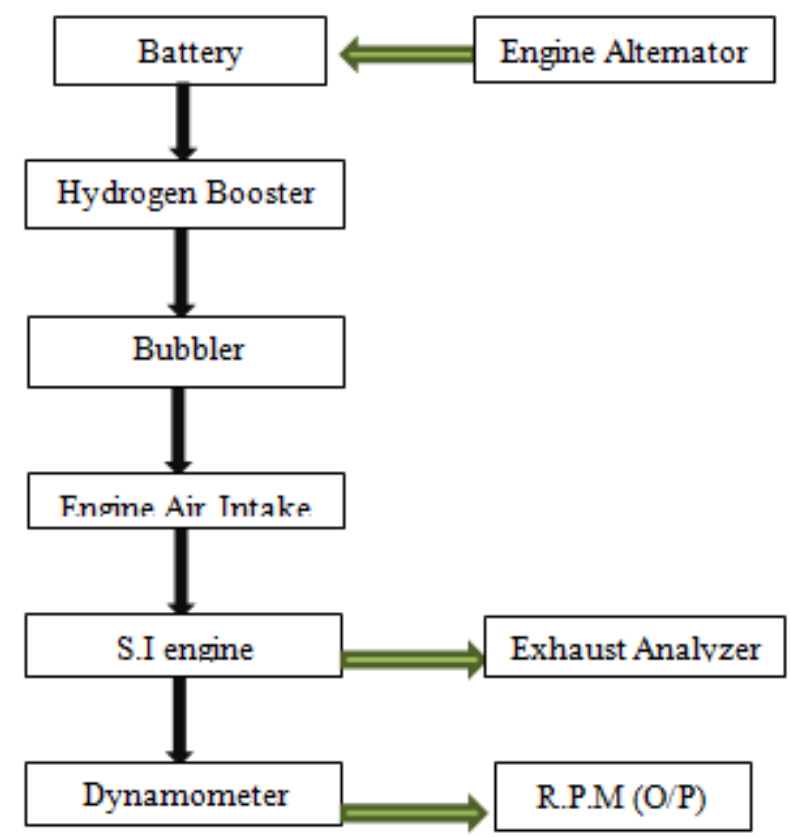

Figure 3: Flow Chart of Experimental Proposed Setup.

Table: 2 Detailed Engine Specifications

\begin{tabular}{|l|l|}
\hline \multicolumn{1}{|c|}{ Engine Type } & \multicolumn{1}{c|}{ In Line Engine } \\
\hline Displacement & $1298(\mathrm{cc})$ \\
\hline Valve Mechanism & SOHC (Abbreviation) \\
\hline Bore & $74(\mathrm{~mm})$ \\
\hline Stroke & $71.5(\mathrm{~mm})$ \\
\hline Gear Box & 5 Speed \\
\hline Compression Ratio & 9.01 \\
\hline Cylinder Configuration & In-line \\
\hline Fuel Type & Petrol \\
\hline No. of Cylinders & Four \\
\hline Ignition Type & Spark \\
\hline
\end{tabular}

\section{METHODOLOGY \& EQUATIONS USED IN CALCULATIONS}

The S.I engine tests was performed to scrutinized the consequences of insertion oxyhydrogen gas in the combustion chamber of a halted spark ignition engine by supplying the exit pipe of oxyhydrogen gas coming out of the bubbler to the air intake before air filter of the engine. This test implies two steps. The initial step entailed manufacturing of oxyhydrogen gas generator and the bubbler. The Oxyhydrogen Gas was generated using the electrolysis process in which the SS-304 low carbon steel sheets were used. The final step entailed us in sending the blending mixture of oxyhydrogen gas and petrol into the combustion chamber of engine. These two phases helped us to obtained the two corresponding outcomes one using 
gasoline as a fuel for the engine and other using a mixture of gasoline and oxyhydrogen gas, from the data obtained we tried to determine the compatibility of using an electrolysis process, powered by the engine, to produce oxyhydrogen gas to enhanced the performance parameters, fuel consumption and improve the emission by reducing the toxins coming out of the engine.

This experimental test with involvement of the electrolysis process computed parameters such as engine emissions, power developed, fuel consumption at different load conditions.

\subsection{Torque ( $T)$}

$\mathrm{T}=\mathrm{W} \times g \times(R+L) \quad \mathrm{N}-\mathrm{m}$

Here, $\mathrm{W}=$ Net Load $=\mathrm{W}_{1}-\mathrm{W}_{2} \quad \mathrm{~kg}$

$\mathrm{g}=$ Acceleration due to gravity $=9.8 \mathrm{~m} / \mathrm{sec}^{2}$

$\mathrm{R}=$ Radius of Drum $=0.133 \quad \mathrm{~m}$

$\mathrm{L}=$ Distance of the spring balance from the centre of shaft $=0.4 \mathrm{~m}$

\subsection{Brake Power (B.P)}

B.P $=\frac{2 \Pi N T}{60 \times 1000} \quad \mathrm{KW}$, here, $\mathrm{N}=$ Speed $/$ R.P.M

\subsection{Fuel Consumption (F.C)}

$\mathrm{F} . \mathrm{C}=\frac{\mathrm{mf} \times 3600 \times \mathrm{df}}{t f \times 1000} \mathrm{Kg} / \mathrm{hr}$, here, $\mathrm{mf}=$ mass of the fuel under observation $\mathrm{ml}$

$\mathrm{df}=$ density of petrol $=0.7 \mathrm{gm} / \mathrm{cc}$

$\mathrm{tf}=$ time for $20 \mathrm{ml}$ of fuel $\mathrm{sec}$

\subsection{Break Specific Fuel Consumption (bsfc)}

$\mathrm{bsfc}=\frac{F . C}{B . P} \mathrm{Kg} / \mathrm{KW} \cdot \mathrm{hr}$

\subsection{Indicated Power (I.P)}

I.P $=$ B.P - B.P $P_{n-1}$, here, B. $P_{n-1}=$ Break power of one less cylinder $\mathrm{n}=$ total no. of cylinders in engine.

\subsection{Performance of Morse Test}

- $\quad$ I.P of $1^{\text {st }}$ Cylinder (I.P 1$)=$ B.P $-(\text { B.P })_{2,3,4}$

- $\quad$ I.P of $2^{\text {nd }}$ Cylinder $($ I.P 2$)=$ B.P $-(\text { B.P })_{1,3,4}$

- $\quad$ (c)I.P of $3^{\text {rd }}$ Cylinder (I.P 3$)=$ B.P $-(B . P)_{1,2,4}$

- $\quad$ I.P of $4^{\text {th }}$ Cylinder (I.P 4$)=$ B.P $-(\text { B.P })_{1,2,3}$

$\mathrm{I} \cdot \mathrm{P}=\mathrm{I} \cdot \mathrm{P}_{1}+\mathrm{I} \cdot \mathrm{P}_{2}+\mathrm{I} \cdot \mathrm{P}_{3}+\mathrm{I} \cdot \mathrm{P}_{4} \mathrm{KW}$ 


\subsection{Frictional Power (F.P)}

F.P $=I . P-$ B.P $\quad K W$

\subsection{Indicated Specific Fuel Consumption (isfe)}

isfc $=\frac{F \cdot C}{I . P} \mathrm{Kg} / \mathrm{KW} \cdot \mathrm{hr}$

\subsection{Mechanical Efficiency $\left(\eta_{\mathrm{m}}\right)$}

$\eta_{\mathrm{m}}=\frac{B . P}{I . P} \times 100 \%$

\section{RESULTS \& DISCUSSIONS}

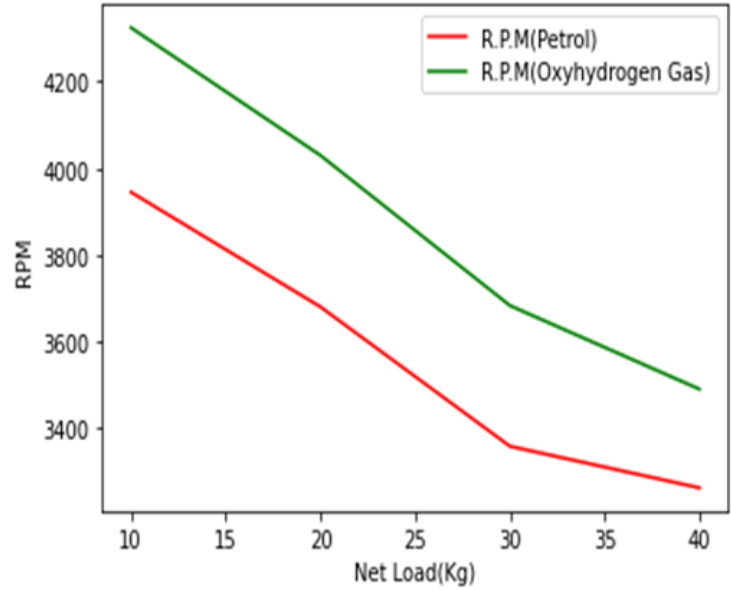

Figure 4: Revolution per Minute Versus Net- Load.

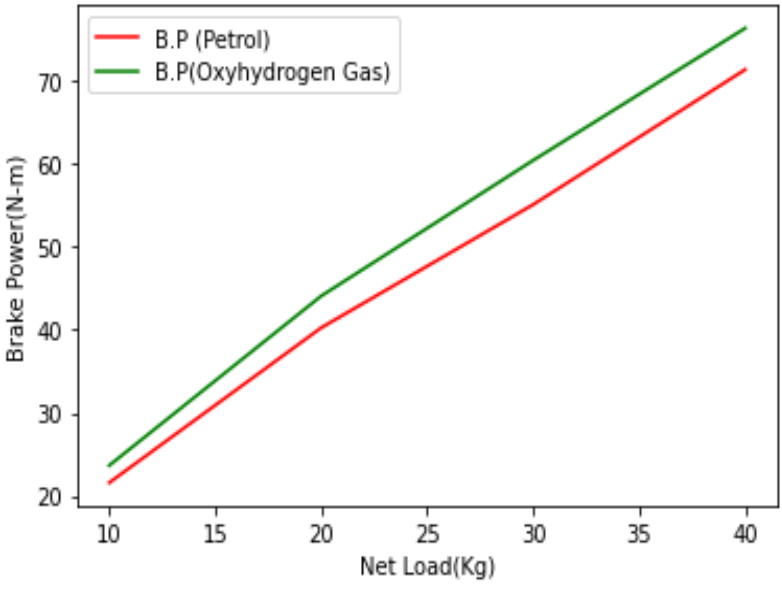

Figure 5: Brake Power Versus Net-Load.

Figure (4) Annotation: It represented the augmentation in R.P.M attained due to the effective and complete ignition inside the combustion chamber when mixture of oxy-hydrogen gas \& petrol was manipulated as fuel with respect to that of gasolineonly. It takes place due to high net heating value of oxyhydrogen as compared to that of petrol.

Figure (5) Annotation: It showed the deviation between brake power of S.Iengine using oxyhydrogen gas and petrol as fuel for the combustion because of the low minimum ignition energy and high chemistry A.F.R for the oxyhydrogen gason mass basis.

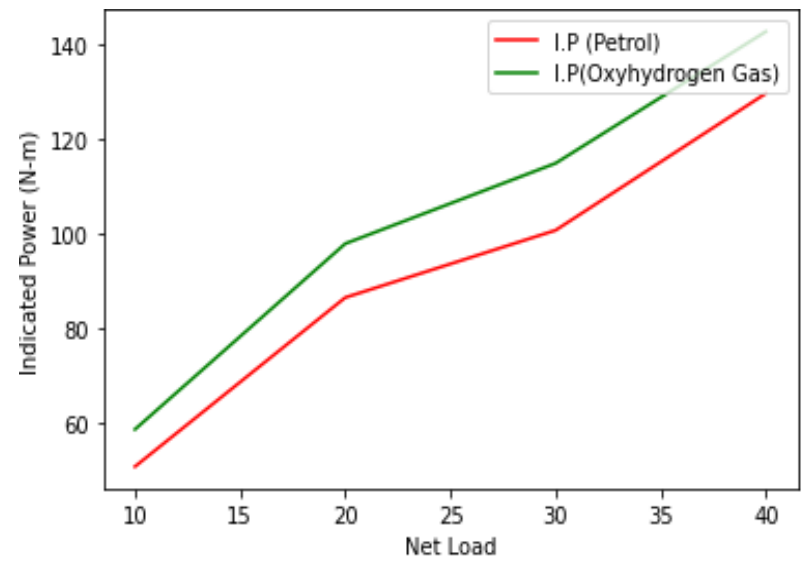

Figure 6: Indicated Power versus Net-Load.

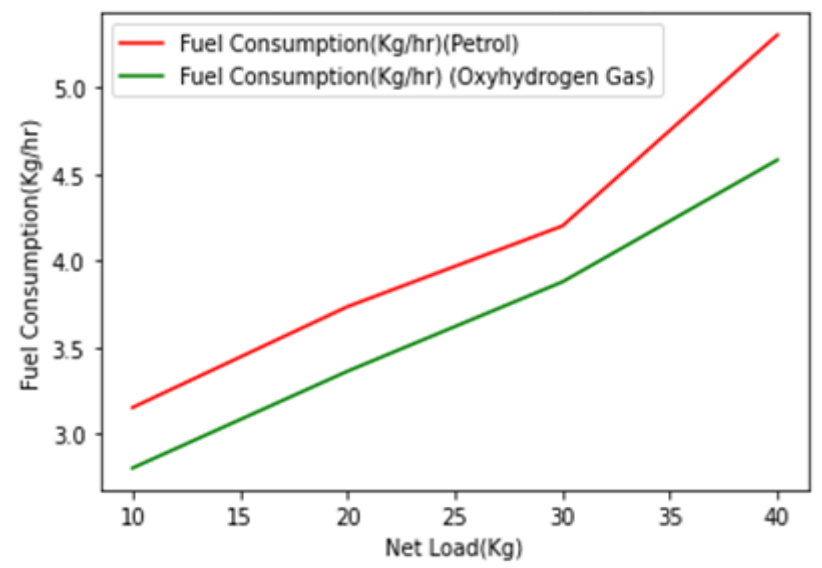

Figure 7: Fuel Consumption Versus Net- Load. 
Figure (6) Annotation: The variation of Indicated power of S.I engine for net- load conditions between oxyhydrogen gas and petrol as fuel was shown in the above figure. The enhancement in the indicated power is attained for the oxyhydrogen gas because of high octane number and more flammability limits.

Figure (7) Annotation: The above figure depicted the reduction in fuel consumption with respect to load variation for the oxyhydrogen gas in compare to petrol only. This reduction occurs due to the veritable or better combustion. This veritable combustion decreases the requirement of fuel consumption for the engine.

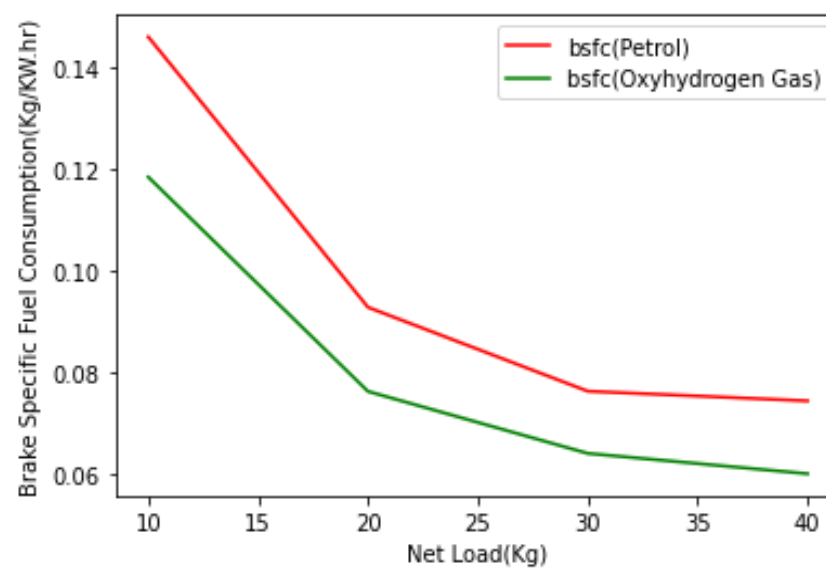

Figure 8: Brake Specific Fuel Consumption Versus Net- Load.

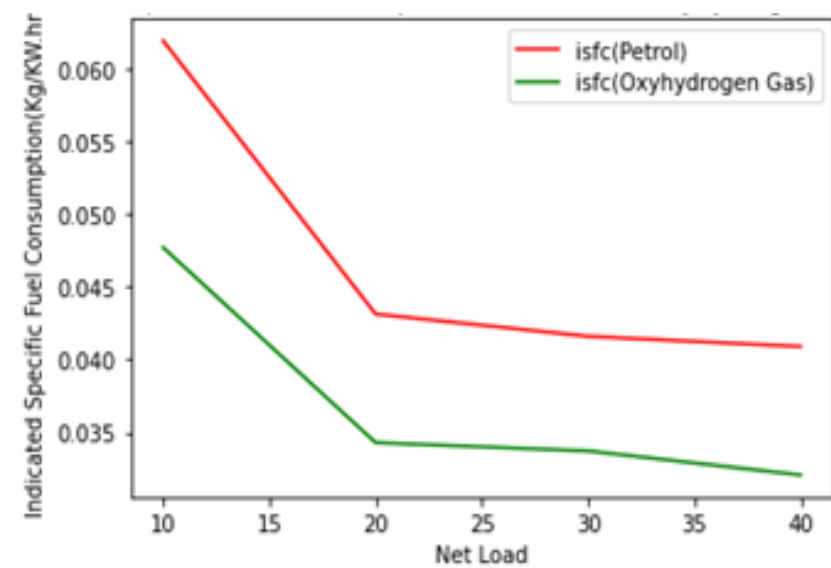

Figure 9: Indicated Specific Fuel Consumption Versus Net Load.

Figure (8) Annotation: The enhancement of brake power and decrease in fuel consumption from the already calculated results due to which the above figure depicts the trend of decrease inbsfc with change in load and also surging in bsfc for oxyhydrogen gas when compared with petrol as fuel.

\subsection{Indicated Specific Fuel Consumption Vs Load (F)}

Figure (9) Annotation: The enhancement of indicated power and decrease in fuel consumption from the already calculated results due to which the above figure depicts the trend of decrease in isfc with the variation in load and also surging in indicated specific fuel consumption for oxyhydrogen gas when compared with petrol as fuel.

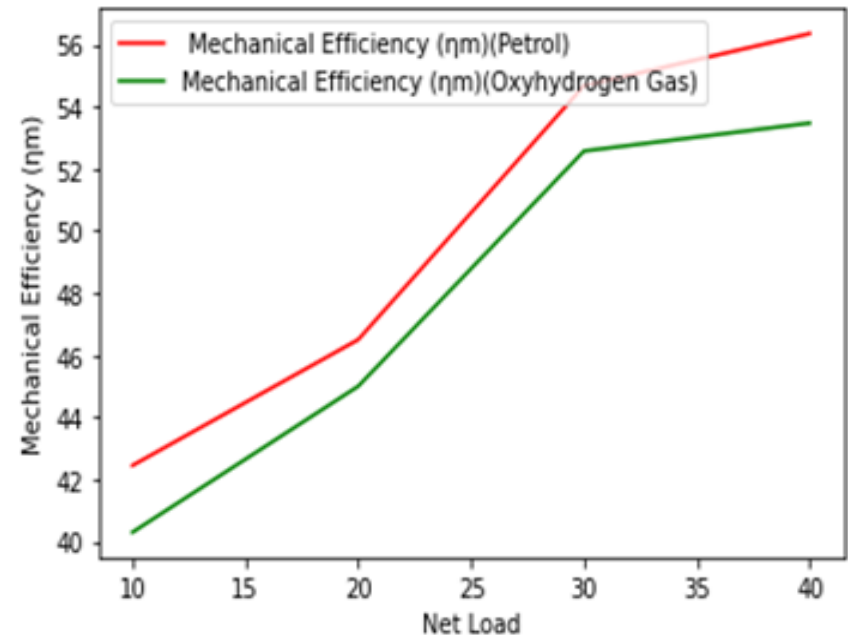

Figure 10: Mechanical Efficiency Versus Net-Load.

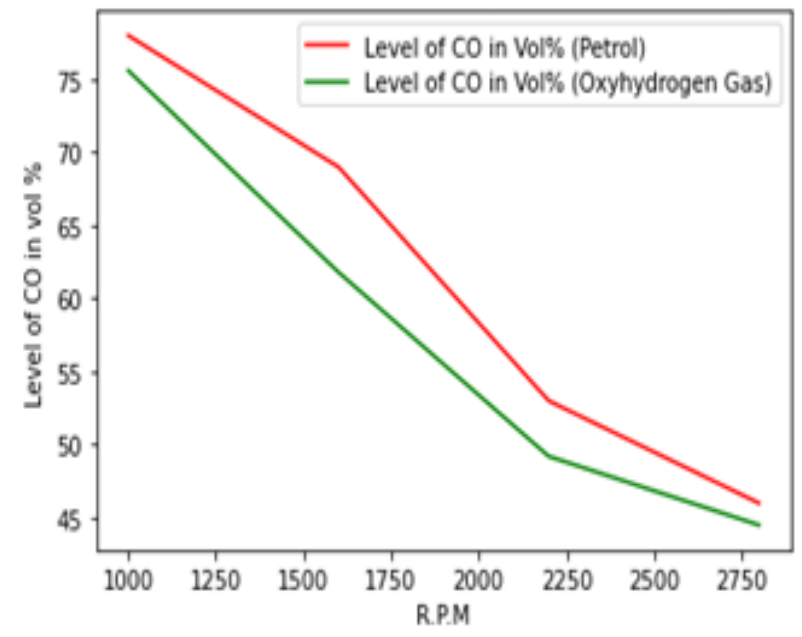

Figure 11: Level of Carbon Monoxide Versus R.P.M.

Figure (10) Annotation: The higher heating value of oxyhydrogen gas in comparison to that of petrol led to the production 
of more heat due to which lot of friction is generated and therefore the mechanical efficiency of the spark ignition engine decreases for oxyhydrogen gas as fuel when compared to petrol only.

Figure (11) Annotation: Above figure depicted the variation of CO with variation in R.P.M. for spark ignition engine. Sabbatical of the element of carbon in oxyhydrogen gas resulted in decrease of carbon monoxide emission from the exhaust gases. Reduced emission of carbon monoxide was obtained when the blending mixture of oxyhydrogen gas and petrol was used for combustion. This reduction in $\mathrm{CO}$ happened due to high flame speed and wide flammability nature of the oxyhydrogen $\operatorname{gas}^{30}$.

\subsection{Level of HC in ppm Vs Load (I)}

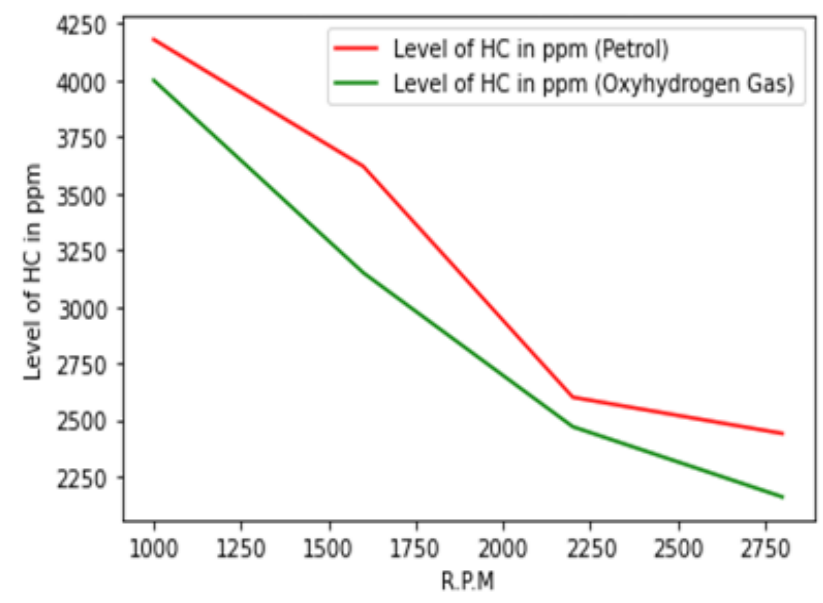

Figure 12: Level of HC in ppm Versus R.P.M.

Figure ( I2) Annotation: T he above figure represented the deviation in hydrocarbon content with the r.p.m variation. Less hydrocarbon content was obtained when oxyhydrogen gas was preowned as fuel dueto high diffusivity, short quenching distance and lack of carbon element in oxyhydrogen gas.

\section{CONCLUSIONS}

In this research work a significant improvement in engine emissions and power development was noticed as a result of oxyhydrogen addition with the conventional gasoline fuel for the spark ignition engine. Oxyhydrogen gas was handed- down as a secondary fuel in a S.I engine $1298 \mathrm{cc}$. Results obtained conclude that by using oxy-hydrogen and gasoline mixture the r.p.m increased by $9 \%$, fuel consumption decreased by $10.80 \%$, brake power increased by $8.61 \%$, indicated power increased by $12.63 \%$ whereas indicated and brake specific fuel consumption decreased by $21.18 \%$ and $18.17 \%$ respectively, also the emission of hydrocarbon decreased by $8.25 \%$ and carbon monoxide decreased by $6.05 \%$. The reduction in mechanical efficiency obtained is $4.31 \%$. The drawback of this research setup is the reduction of mechanical efficiency due to enhancement in frictional losses because of high heat generation during combustion. The generation rate of oxyhydrogen gas through the process of electrolysis was directly proportional to voltage and current. Frictional power increases with load and oxyhydrogen injection rate. In this research work a significant improvement in engine emissions and power development was noticed as a result of oxy-hydrogen addition with the conventional gasoline fuel for the spark ignition engine. Oxyhydrogen generator and supplying system can be made compatible to the engine without any major modification which approaches towards better results 


\section{REFERENCES}

1. Khatri, N. \& Khatri, K. K. Hydrogen enrichment on diesel engine with biogas in dual fuel mode. Int. J. Hydrogen Energy45, $7128-7140(2020)$.

2. Kumar Sharma, P. et al. Energy, exergy, and emission analysis of a hydroxyl fueled compression ignition engine under dual fuel mode. Fuel265, 116923 (2020).

3. Murali, Binkam Naga, KVP Chakradhar, and G. Swaroop Kumar Yadav. "Experimental Investigation to Determine the Effect of Hho Booster on the Performance of a two Wheeler."

4. Deheri, C., Acharya, S. K., Thatoi, D. N. \& Mohanty, A. P. A review on performance of biogas and hydrogen on diesel engine in dual fuel mode. Fuel260, 116337 (2020).

5. Salek, F., Zamen, M. \& Hosseini, S. V. Experimental study, energy assessment and improvement of hydroxy generator coupled with a gasoline engine. Energy Reports6, 146-156 (2020).

6. Xu, H. et al. Towards online optimisation of solid oxide fuel cell performance: Combining deep learning with multi-physics simulation. Energy AI1, 100003 (2020).

7. Jindal, Himanshu, Amandeep Singh Oberoi, and Inderjeet Singh Sandhu. "A Reduced Graphene Oxide Electrode for Solid-State Hydrogen Storage within a Proton Battery."International Journal of Mechanical and Production Engineering Research and Development IJMPERD) 9, Issue 4, Aug 2019, 659-670

8. Mourad, M. \& Mahmoud, K. Investigation into SI engine performance characteristics and emissions fuelled with ethanol/butanol-gasoline blends. Renew. Energy143, 762-771 (2019).

9. Abe, J. O., Popoola, A. P. I., Ajenifuja, E. \& Popoola, O. M. Hydrogen energy, economy and storage: Review and recommendation. Int. J. Hydrogen Energy44, 15072-15086 (2019).

10. Majeed, Munaf S., Tagreed K. Hamad, and Emadtalib Hashim. "Zno Nanoparticle Synthesis using Nd: Yag Laserfor Increasing Hydrogen Fuel Cell Performance."International Journal of Mechanical and Production Engineering Research and Development (IJMPERD) ISSN(P): 2249-6890; ISSN(E): 2249-8001 Vol. 8, Issue 6, Dec 2018, 497-506

11. Neshat, E., Bajestani, A. V. \& Honnery, D. Advanced numerical analyses on thermal, chemical and dilution effects of water addition on diesel engine performance and emissions utilizing artificial inert species. Fuel242, 596-606 (2019).

12. Senthil Kumar, M., Arul, K. \& Sasikumar, N. Impact of oxygen enrichment on the engine's performance, emission and combustion behavior of a biofuel based reactivity controlled compression ignition engine. J. Energy Inst.92, 51-61 (2019).

13. Choodum, N., Sangwichien, C. \& Yamsaengsung, R. Optimization of a closed-loop HHO production system for vehicles and houses. Environ. Prog. Sustain. Energy38, 268-277 (2019).

14. Shingane, S., et al. "The Electrolysis of Water To Generate Hydrogen (Hho) and A Study of the Effect of Addition of Hho to Gasoline as an Engine Performance Improver. "International Journal of Mechanical and Production Engineering Research and Development (IJMPERD) 8. 8, Oct 2018, 181-186

15. Karagöz, Y., Balcl, Ö. \& Köten, H. Investigation of hydrogen usage on combustion characteristics and emissions of a spark ignition engine. Int. J. Hydrogen Energy 1-14 (2019) doi:10.1016/j.ijhydene.2019.01.147.

16. Koten, H. Hydrogen effects on the diesel engine performance and emissions. Int. J. Hydrogen Energy43, 10511-10519 (2018).

17. Al-Rousan, A. A. Reduction of fuel consumption in gasoline engines by introducing HHO gas into intake manifold. Int. J. Hydrogen Energy35, 12930-12935 (2010). 
18. Azizzadeh Hajlari, S., Najafi, B. \& Faizollahzadeh Ardabili, S. Castor oil, a source for biodiesel production and its impact on the diesel engine performance. Renew. Energy Focus28, 1-10 (2019).

19. Sakthivel, G., Sivaraja, C. M. \& Ikua, B. W. Prediction OF CI engine performance, emission and combustion parameters using fish oil as a biodiesel by fuzzy-GA. Energy 287-306 (2019) doi:10.1016/j.energy.2018.10.023.

20. Senthil Kumar, M., Karthic, S. V. \& Pradeep, P. Investigations on the influence of ethanol and water injection techniques on engine's behavior of a hydrogen - biofuel based dual fuel engine. Int. J. Hydrogen Energy43, 21090-21101 (2018).

21. Chiriac, $R$. et al. On the possibility to improve petrol engine operation by laser ignition. Energy Procedia157, 1022-1028 (2019).

22. Nabi, M. N. \& Rasul, M. G. One-dimensional thermodynamic model development for engine performance, combustion and emissions analysis using diesel and two paraffin fuels. Energy Procedia156, 259-265 (2019).

23. Esonye, C., Onukwuli, O. D., Ofoefule, A. U. \& Ogah, E. O. Multi-input multi-output (MIMO) ANN and Nelder-Mead's simplex based modeling of engine performance and combustion emission characteristics of biodiesel-diesel blend in CI diesel engine. Appl. Therm. Eng.151, 100-114 (2019).

24. Adio, T. A. et al. Determination of a spark ignition engine's performance parameters using response surface methodology. in Energy Procedia vol. 157 1412-1422 (Elsevier B.V., 2019).

25. Ghazal, O. H. Combustion analysis of hydrogen-diesel dual fuel engine with water injection technique. Case Stud. Therm. Eng.13, 100380 (2019)

26. Sheykhi, M. et al. Performance investigation of a combined heat and power system with internal and external combustion engines. Energy Convers. Manag.185, 291-303 (2019).

27. Güven, M., Bedir, H. \& Anlaş, G. Optimization and application of stirling engine for waste heat recovery from a heavy-duty truck engine. Energy Convers. Manag.180, 411-424 (2019).

28. Nour, M., Attia, A. M. A. \& Nada, S. A. Combustion, performance and emission analysis of diesel engine fuelled by higher alcohols (butanol, octanol and heptanol)/diesel blends. Energy Convers. Manag.185, 313-329 (2019).

29. Hassantabar, A., Najjaran, A. \& Farzaneh-Gord, M. Investigating the effect of engine speed and flight altitude on the performance of throttle body injection (TBI) system of a two-stroke air-powered engine. Aerosp. Sci. Technol.86, 375-386 (2019).

30. Zhang, Y. et al. Engine performance and octane on demand studies of a dual fuel spark ignition engine with ethanol/gasoline surrogates as fuel. Energy Convers. Manag.183, 296-306 (2019).

31. Yao, C., Li, X., Zang, $R . \& X u, Y$. Research on the performance of an electronically controlled spark ignition engine fuelled with hydrogen-rich gases. Proc. Inst. Mech. Eng. Part D J. Automob. Eng.228, 1084-1094 (2014).

32. Abe, I. Hydrogen Production by Water Electrolysis. in Hydrogen Energy system vol. 33 19-26 (2017).

33. Santilli, R. M. A new gaseous and combustible form of water. Int. J. Hydrogen Energy31, 1113-1128 (2006).

34. Bhardwaj, S., Singh Verma, A. \& Sharma, S. K. Effect of brown gas on the performance of a four stroke gasoline engine. in International Journal of Emerging Technology and Advanced Engineering vol. 4 2250-2459 (2014). 
